\title{
Physiological response of marandu grass seeds exposed to NPK fertilizer
}

\author{
Luciane da Cunha Codognoto ${ }^{1^{*}}$ (iD) Thassiane Telles Conde ${ }^{1}$ Kátia Luciene Maltoni $^{2}$ \\ Glaucia Amorim Faria ${ }^{2}$ André Rodrigues dos Reis ${ }^{2}$
}

\author{
${ }^{1}$ Instituto Federal de Educação, Ciência e Tecnologia de Rondônia (IFRO), 76870-970, Ariquemes, RO, Brasil. E-mail: luciane.codognoto@ifro.edu.br. \\ *Corresponding author. \\ ${ }^{2}$ Programa de Pós-Graduação em Agronomia (PPCA), Universidade Estadual Paulista "Júlio de Mesquita Filho" (UNESP), Ilha Solteira, SP, Brasil.
}

ABSTRACT: To facilitate seeding process of forage species, a common practice is to mix seeds with fertilizers in monocropping and intercropping or in implementing integrated livestock production systems. However, in prolonged periods of contact, the fertilizer's salinity and acidity negatively affect the seeds' physiological quality. Therefore, this study intends to verify the effect of ten periods (0, 3, 6, 12, 24, 36, 48, 72, 96, and 120 hours) of exposure to granular NPK fertilizer 04-30-16 on the vigor and germination of Urochloa brizantha cv. Marandu seeds. The experiment was conducted in a completely randomized design with three replication. The fertilizer and seed mixture registered a negative effect on seed moisture content, electrical conductivity, emergence, emergence speed index, and seedling and radicle length as the period of exposure to the fertilizer increased from 3 to 120 hours.

Key words: Brachiaria, ionic effect, germination, osmotic effect, salinity.

Resposta fisiológica de sementes de capim marandu expostas ao fertilizante NPK

RESUMO: Para facilitar o processo de semeadura de espécies forrageiras é comum a mistura de sementes com fertilizantes, seja em cultivo exclusivo, consorciado ou na implantação de sistemas integrados de produção agropecuária. Entretanto, a salinidade e acidez do fertilizante, em longos períodos de mistura, supõe-se ação deletéria na qualidade fisiológica das sementes. Dessa forma, o estudo teve como objetivo verificar o efeito de dez tempos de mistura (0, 3, 6, 12, 24, 36, 48, 72, 96 e 120 horas) do fertilizante granulado NPK 04-30-16, sobre vigor e germinação de sementes de Urochloa brizantha $\mathrm{cv}$. Marandu. O experimento foi conduzido em delineamento experimental inteiramente casualizado, com três repetições. Houve efeito negativo da mistura de fertilizante com as sementes para o grau de umidade, condutividade elétrica, emergência, índice de velocidade de emergência, comprimentos de plântula e de radícula em função do incremento do tempo de mistura com fertilizante, de 3 a 120 horas de exposição.

Palavras-chave: Brachiaria, efeito iônico, germinação, osmótico, salinidade.

\section{INTRODUCTION}

Animal husbandry is one of the agricultural sectors main areas for negotiation in Brazil's balance of trade (CNA, 2019, USDA, 2019). Perennial pastures, such as Urochloa brizantha species (syn Brachiaria brizantha) are used for cattle grazing and have low production costs as they can utilize soils with low natural fertilities; making them essential for economic success of the cattle grazing industry. However, certain circumstances during crop establishment in perennial pastures make them less productive and more vulnerable to degradation. These circumstances include: improper soil preparation, low-quality seeds, seeding at an inappropriate period or inadequate depth (DIAS-FILHO, 2012), and exposure of forage seeds to inorganic fertilizers
(MATEUS et al., 2007; FOLONI et al., 2009; LIMA et al., 2010). Fertilizers are chemical compounds capable of providing nutritious resources in the growing environment, especially the edaphic, to full development of cultivated plants.

In pasture recovery or renewal and in implementation of integrated livestock production systems, forage seed is mixed with fertilizer in the distribution box of the seeding equipment to facilitate dispersal. This technique ensures that seed and fertilizer distribution are optimized during sowing process. However, this practice may result in the seeds being mixed with the fertilizer for long periods of time, which can negatively impact on seed quality. Acidic residues of phosphorus and salinity of nitrogen and potassium, which constitute NPK fertilizers, damage the physiology of seeds that 
have had prolonged exposure to them (MATEUS et al., 2007; LIMA et al., 2009; LIMA et al., 2010; BU et al., 2015).

Nitrogen fertilizers, such as urea, have the potential to release ammonia $\left(\mathrm{NH}_{3}\right)$, especially when high doses are applied in the furrows for seeding, and this can create toxic conditions for seeds (SANGOI et al., 2009; FERRARI et al., 2013). The likely effects of saline toxicity are ionic and osmotic. Ionic effects result in altered enzymatic processes, disturbances in the accumulation and transport of different ions, or a combination of these factors (ADILOGLU et al., 2007). Osmotic effects compromise germination as they disturb the gradient on the seed's surface, thereby limiting water absorption and causing physiological dryness (PEREIRA et al., 2012; SOARES et al., 2015). Consequently, the expected plant populations or crop stands decrease (DELATORRE-HERRERA and PINTO, 2009; BAJJI et al., 2002; BU et al., 2015), and the formation of abnormal seedlings harms the initial establishment (LIMA et al., 2009; MASETTO et al., 2013), and compromises productive capacity. In general, salinity significantly impacts plant establishment and delays emergence (DEBEZ et al., 2004; FERRARI et al., 2013). The amount of time in which the seed is exposed to the fertilizer can affect it physiologically, thus altering germination and vigor, due to the fertilizers' saline and toxic effects (CAVARIANI, et al., 1994; LIMA et al., 2009).

MATTEI et al. (2015) evaluated the effects of nitrogen, phosphate, and potassium fertilizers after different periods of contact with U. ruziziensis seeds and observed that there was no effect on seedling length; however, seedling dry matter production was influenced by increased contact periods. The depressive effect of saline fertilizers (potassium chloride>urea) was significant for seedling dry mass compared with the acid treatments (single superphosphate) and the control (no fertilizer). After 96 hours of contact, there was a $36 \%$ reduction in dry mass production in comparison with the control.

This study aimed to verify the effects that different periods of exposure to the granular NPK [0430-16] fertilizer have on the vigor and germination of Marandu grass seeds (U. brizantha cv. Marandu, syn. Brachiaria brizantha).

\section{MATERIALS AND METHODS}

Seeds Urochloa brizantha cv. Marandu (Marandu grass) were obtained from a commercial lot of the 2015/2016 crop with a cultivation value (VC) of $80 \%$. Treatments consisted of ten periods
$(0,3,6,12,24,36,48,72,96$, and 120 hours $)$ in which the seeds were exposed to granular compound fertilizer containing $\mathrm{N}-\mathrm{P}_{2} \mathrm{O}_{5}-\mathrm{K}_{2} \mathrm{O}$, 04-30-16. The experimental design was completely randomized and had ten treatments (periods exposed to the mixture) with three replications.

The granulated fertilizers 04-3016 composition was defined according to $\mathrm{P}_{2} \mathrm{O}_{5}$ recommendations for grasses (ALVES et al., 1999) and mixed at a sowing rate equivalent to $5.6 \mathrm{~kg}$ of viable pure seed (VPS) per hectare. Therefore, the mixing ratio equated to 28: 1 (28 $\mathrm{g}$ of fertilizer per 1 $\mathrm{g}$ of VPS). The mixture was packed into raffia bags, simulating a practice adopted by farmers.

After the VPS were exposed for periods of $0,3,6,12,24,36,48,72,96$, and 120 hours to the fertilizer, batches were collected at random for manual separation of VPS from the fertilizer using tongs, brushes, and trays to determine the seeds' physiological qualities.

The electrical conductivity (EC) was determined using the bulk method, wherein trials of 50 VPS were deposited in plastic cups containing 75 $\mathrm{ml}$ of distilled water and kept at $20{ }^{\circ} \mathrm{C}$ for 24 hours (VIEIRA and KRZYZANOWSKI, 1999). After this period, e electrical conductivity of the solution was measured with a bench top digital electrical conductivity meter.

Seed moisture content (SMC) was determined by applying the greenhouse method at $105^{\circ} \mathrm{C}$ for 24 hours (BRASIL, 2009) and using three trials with five grams of VPS per treatment, adjusted for percentage.

To assess germination (GER), 50 VPS per experimental unit were utilized. They were seeded in rolls of paper suitable for seed germination, moistened with distilled water at 2.5 times the papers mass and stored in a BOD seed germinator at a constant temperature of $20{ }^{\circ} \mathrm{C}$ and no light (BRASIL, 2009). Normal seedlings were counted seven and 21 days after the test to gather data of the first germination count (FGC) and germination (GER), respectively. Results were expressed as percentages of normal seedlings.

The emergence speed index (ESI) was determined for 50 VPS per experimental unit. The seeds were deposited at a depth of one centimeter in an autoclaved soil substrate, with a mean density of 1.1 $\mathrm{kg} \mathrm{m}^{-3}$ and a humidity at $60 \%$ of field capacity. The ESI was determined based on daily emergence counts and the equation proposed by MAGUIRE (1962) (eq. 1):

$\mathrm{ESI}=\mathrm{E} 1 / \mathrm{N} 1+\mathrm{E} 2 / \mathrm{N} 2+\mathrm{En} / \mathrm{Nn}$

Where: ESI is the emergence speed index;

E1, E2... Enare the quantitative values of normal 
seedlings observed in the first (E1) up to the last count (En); and N1, N2. Nnare the quantitative values for seeding days in the first (N1) up to the last count (Nn).

Using the ESI test, we examined seedling emergence (EMER) from the moment of first seedling emerged until stabilization (BRASIL, 2009). Upon the final count, we determined the percentage of emerged seedlings.

After 7 days of seeding, the GER test was applied to measure the lengths of the radicles (RL) (below the cotyledon to the tip of the radicle) and seedlings (SL) (from the tip of the coleoptile to the tip of the radicle) in five sub-samples per experimental unit.

The data were analyzed by variance through the F-test, using SISVAR software (FERREIRA, 2014). When significant differences were reported, we performed the analysis of variance within the regression model.

\section{RESULTS}

From the analysis of variance, the $\mathrm{F}$ test indicated significant differences for CE, SMC, ESI, EMER, RL, and SL (Table 1); evidencing the effect that contact time with the fertilizer has on the seeds physiological qualities. The test showed no significant effects for the EC and SMC ( $\mathrm{P}>0.05)$ (Table 1).

Increasing duration of contact of the Marandu grass seed with the fertilizer influenced both $\mathrm{EC}$ and SMC, with their behaviors being adapted to the positive linear regression model, characterizing directly proportional effects of exposure (Figure
$1 \mathrm{~A}$ and 1B). The highest values for EC (32.16 and $32.39 \mu \mathrm{S} \mathrm{cm}^{-1} \mathrm{~g}^{-1}$, respectively) were obtained after exposure times of 96 and 120 hours, characterizing high salt concentration at these times. The SMC after 120 hours' of exposure time was superior to the others studied, especially of those immediately sown (0 hours of exposure time).

The ESI showed linear performance (Figure 1C), characterizing the behavior as inversely proportional to the time of contact with the fertilizer; after the maximum time of exposure to the fertilizer (120 hours), ESI and EMER were reduced (Figure 1D). The lowest percentage of EMER (26.67\%) also occurred after the maximum contact time with the fertilizer (120 hours).

There was a negative effect on RL and SL, caused by direct contact with the fertilizer, that progressively restricted the plant growth capacity as the exposure time of the seeds increased. This behavior adjusted to the linear regression model (Figures 1E and 1F), further emphasized that immediate seeding ( 0 hour) presents better results than when there are prolonged exposures of the seeds to the fertilizer (120 hours).

\section{DISCUSSION}

Mixture of seeds and fertilizer increased the contact surface and intensified both the saline action of the nitrogen and potassium elements (MATEUS et al., 2007; DAN et al., 2011) and the acidic action of the phosphate component of the fertilizer (MATEUS et al., 2007; LIMA et al., 2010; PERES et al., 2012).

Table 1 - Results from the analysis of variance for electrical conductivity, seed moisture content, first germination count, germination, radicle and seedling lengths, emergence speed index, and emergence of Urochloa Brizantha cv. Marandu as a function of the exposure time to the granular compound NPK[04-30-16] fertilizer.

\begin{tabular}{lccc}
\hline Variables & Exposure time & Coefficient of variation & General Mean \\
\hline & F Value & $(\%)$ & 11.58 \\
Electrical conductivity $\left(\mu \mathrm{S} . \mathrm{cm}^{-1} \mathrm{~g}^{-1}\right)$ & $4.408^{* *}$ & 2.25 & 10.49 \\
\hline Seed moisture content $(\%)$ & $2.794^{*}$ & 12.74 & 56.47 \\
\hline First germination count $(\%)$ & $2.016^{\text {ns }}$ & 15.78 & 69.33 \\
Germination $(\%)$ & $0.526^{\mathrm{ns}}$ & 16.75 & 4.91 \\
Emergence speed index & $8.769^{* *}$ & 22.10 & 50.93 \\
Emergence $(\%)$ & $2.436^{*}$ & 8.47 & 55.43 \\
Radicle length $(\mathrm{mm})$ & $19.915^{* *}$ & 8.90 & 93.22 \\
\hline Seedling length $(\mathrm{mm})$ & $20.106^{* *}$ & \\
\hline
\end{tabular}

**, , and ${ }^{\mathrm{ns}}$ correspond to significance values of $P \leq 0.01, P \leq 0.05$, and not significant, respectively, by the F-test. 

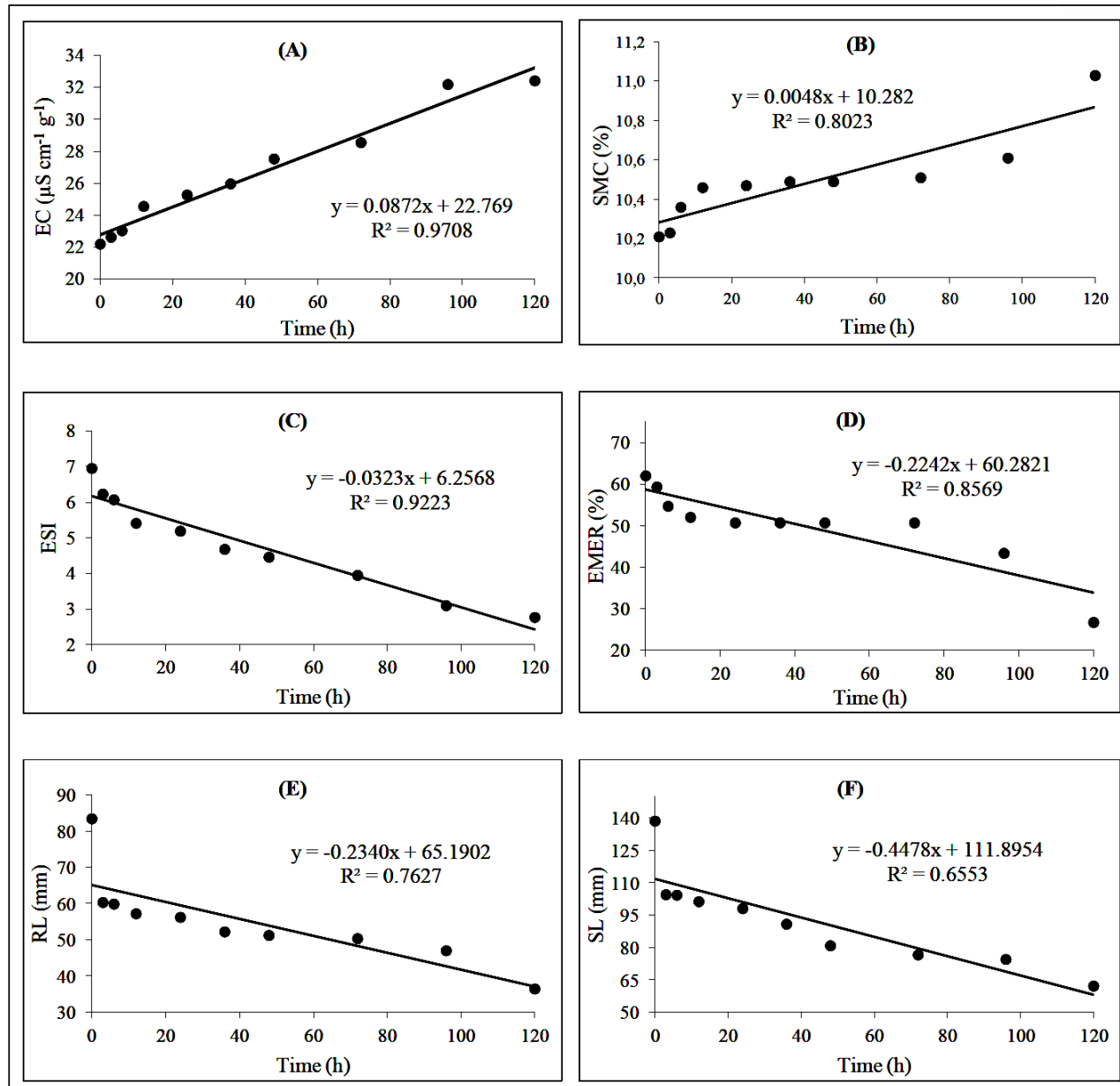

Figure 1 - Regression equations and coefficients of determination for electrical conductivity (EC), seed moisture content (SMC), emergence speed index (ESI), emergence (EMER), radicle (RL) and seedling lengths (SL) as a function of Urochloa brizantha cv. Marandu seeds' exposure time to granular NPK [04-3016] fertilizer.

With increased periods of contact of the seeds with the fertilizer, the harmful effects to its coating structure intensified (SILVA et al., 2014), releasing cellular cytoplasmic solutes into the liquid medium (Figure 1A), namely the potassium ion (MARCOSFILHO, 2015), that altered the values for EC. Similarly, AVELINO et al. (2018) using fertilizer 0525-15, observed an EC of $22.74 \mu \mathrm{S} \mathrm{cm}^{-1} \mathrm{~g}^{-1}$, agreeing with that recorded for the fertilizer used in this study (22.17 $\left.\mu \mathrm{Scm}^{-1} \mathrm{~g}^{-1}\right)$, for immediate seeding. However, at the seed's maximum exposure time (96 hours), AVELINO et al. (2018) registered an EC of $66.49 \mu \mathrm{S}$ $\mathrm{cm}^{-1} \mathrm{~g}^{-1}$, which signifies an elevated level of salt/ions in the solution, nearly $207 \%$ of the value we obtained for the same exposure time in this study. Similarly, $\mathrm{SMC}$ was affected by the period of exposure to the fertilizer (Figure 1B). Nonetheless, the SMC values are suitable for $U$. brizantha seeds, as noted by PARIZ et al. (2010). This indicated that the mixture's conditions during the experiment prevented either the environment's relative humidity or the fertilizer's critical relative humidity from negatively altering the seed's optimum moisture content (between 10 and $11 \%$, moisture basis), consequently preserving the Marandu grass seeds' physiological qualities.

The fertilizer's salinity reduced ESI by $60 \%$ at seeds' maximum time of exposure to the fertilizer (120 hours) compared to immediate seeding value (Figure 1C). The lowest ESI values are related to the seed's lower respiratory activity and release of leachates (TORRES et al., 2016), caused by the reduced EC, brought on by the increased period of 
exposure to the fertilizer (Figure 1A). Thus, seeds tend to have increasingly less vigor after the progressively increased exposures to the NPK [04-30-16] fertilizer, registering low and uneven emergence, giving rise to seedlings with undesirable and competitive characteristics (Figure 2).

Fertilizer's direct contact with the seeds inhibited enzymes action from converting reserved substances into assimilates necessary for EMER (ADEM et al., 2014; BU et al., 2015); characterizing the deterioration by the fertilizer as an irreversible process. Accordingly, ESI and EMER are intensely affected by the fertilizer's action (FOLONI et al., 2009). EMER behavior was similar to that of ESI, registering physiological and biochemical disturbances that impeded or delayed EMER, especially after 120 hours of exposure (Figure 1D). In practical terms, prolonged exposures (120 hours) created an economic loss of $57 \%$ of the investment, for the acquisition of seeds, by reducing the number of seedlings.

Prolonged contact with the fertilizer inhibited growth or resulted in abnormal seedlings (Figure 1). Fertilizer's damage to the seed is especially notable in the radicle (BEVILAQUA et al.,
1996); a structure essential to the plant's productivity. Degenerative changes in the seeds' physiological qualities yielded smaller seedlings, particularly from the exposure time of 3 hours onwards (Figure 1), by annihilating the integrity of the cellular systems and affecting the translocation of the endosperm's nutritive reserves to the cotyledon, consequently impairing the embryo's growth.

DAN et al. (2011) evaluated U. ruziziensis seeds exposed to nitrogen fertilizer (urea) and reported that after 16 hours of exposure, there was a reduction in seedling length equal to $10 \%$, compared with those that had been immediately seeded. Conversely, MATTEI et al. (2015) studied the effect of nitrogen, phosphate, and potassium fertilizers on U. ruziziensis seeds after different durations of contact and observed no effect on seedling length. In this case, the seeds' greatest exposure to the fertilizer (120 hours) limited the growing capacities of the aerial and radicular structures of the Marandu grass seedlings by up to $45 \%$ (Figure $1 \mathrm{E}$ and $1 \mathrm{~F}$ ), consequently, decreasing access to nutrients and water, and creating greater susceptibility to abiotic stresses (MATEUS et al., 2007; LIMA et al., 2009; LIMA et al., 2010; DAN et al., 2011).

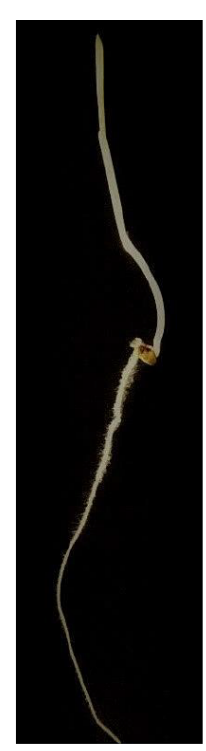

(A)

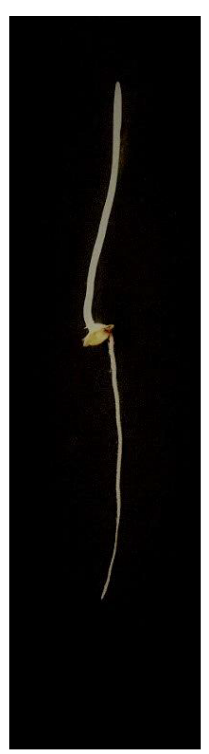

(B)

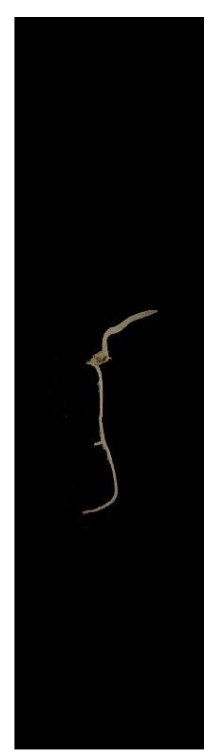

(C)

Figure 2 - Effect of (A) 0h, (B) 24h, and (C) 120h of exposure to granular NPK [04-3016] fertilizer on Urochloa brizantha cv. Marandu seedlings. 


\section{CONCLUSION}

After 3 hours of exposure, the mixture of Marandu grass seeds with the NPK [04-30-16] fertilizer compromised the seeds' vigor, reduced the expected population, seedling and rootlet lengths.

\section{ACKNOWLEDGMENTS}

We thank the of the Federal Institute of Education, Science, and Technology of Rondônia (IFRO), Ariquemes Campus, for the opportunity, and the agronomic engineer Andreza P. S. Cruz, of Sementes OestePaulista (SOESP), for providing the seeds. And was financed in part by the Coordenação de Aperfeiçoamento de Pessoal de Nível Superior (CAPES), Brasil.

\section{DECLARATION OF CONFLICT OF INTERESTS}

The authors declare no conflict of interest. The founding sponsors had no role in the design of the study; in the collection, analyses, or interpretation of data; in the writing of the manuscript, and in the decision to publish the results.

\section{AUTHORS' CONTRIBUTIONS}

The authors contributed equally to the manuscript.

\section{REFERENCES}

ADEM, G. D. et al. Evaluating contribution of ionic, osmotic and oxidative stress components towards salinity tolerance in barley. BMC Plant Biology, v.14, n.113, p.13, 2014. Available from: <https://bmcplantbiol.biomedcentral.com/ articles/10.1186/1471-2229-14-113>. Accessed: Jan. 10, 2018. doi: 10.1186/1471-2229-14-113

ADILOGLU, S. et al. Effect of different levels of $\mathrm{NaCL}$ and $\mathrm{KCl}$ on growth and some biological indexes of wheat plant. Pakistan Journal of Biological Sciences, v.10, n.11, p.1941-1943, 2007. Available from: $<$ https://scialert.net/fulltextmobile/?doi=pj bs.2007.1941.1943>. Accessed: Oct. 12, 2018. doi: 10.3923/ pjbs.2007.1941.1943

ALVES, V. M. C. et al. Milho. In: RIBEIRO, A.C. et al. (eds). Recomendação para o uso de corretivos e fertilizantes em Minas Gerais. 5a aproximação. Viçosa, MG, CFSEMG, 1999. p.315-316.

AVELINO, A. C. D. et al. Immediate sowing of piatã grass seed associate with fertilizer for minimum germination in integrate systems. Acta Iguazu, v.7, n.1, p.75-86, 2018. Available from: $<$ http://e-revista.unioeste.br/index.php/actaiguazu/article/ view/16450>. Accessed: Sep. 09, 2018.

BAJJI, M. et al. Osmotic and ionic effects of $\mathrm{NaCl}$ on germination, early seedling growth, and ion content of Atriplex halimus (Chenopodiaceae). Canadian Journal of Botany, v.80, n.3, p.297-304, 2002. Available from: <https://www.nrcresearchpress. com/doi/10.1139/b02-008\#.XNS6NY5KjIU>. Accessed: Jan. 08, 2019. doi: 10.1139/b02-008.

BEVILAQUA, G. A. P. et al. Effect of fertilizer rates and placement on soybean seeds stablishment and nutriente uptake. Revista Brasileira de Sementes, v.18, n.1, p.45-49, 1996. Accessed: Jun. 18, 2017. doi: 10.17801/0101-3122/rbs.v18n1p45-49.
BRASIL. Ministério da Agricultura, Pecuária e Abastecimento. Regras para análise de sementes. Ministério da Agricultura, Pecuária e Abastecimento. Secretaria de Defesa Agropecuária. Brasília: Mapa/ACS. 2009. 395p. Available from: <http://www. agricultura.gov.br/assuntos/laboratorios/arquivos-publicacoeslaboratorio/regras-para-analise-de-sementes.pdf/view>. Acessed: Feb. 12, 2017

BU, Y. et al. Adverse effect of urease on salt stress during seed germination in Arabidopsis thaliana. FEBS Letters, v.589, n.12, p.1308-1313, 2015. Available from: < https://www.sciencedirect. com/science/article/pii/S0014579315002549>. Accessed: Jan. 29, 2018. doi: 10.1016/j.febslet.2015.04.016.

CAVARIANI, C. et al. Mixture of fosfate fertilizers with Brachiaria decumbens Stapf and Brachiaria brizantha (HochstEx A. Rich) Stapf. Revista Brasileira de Sementes, v.16, n.2, p.163167, 1994. Acessed: Mar. 16, 2018. doi: 10.17801/0101-3122/rbs. v16n2p163-167.

CONFEDERAÇÃO NACIONAL DA AGRICULTURA - CNA. Cenário para 2019 é de safra maior de grãos, alta do PIB e do faturamento do agro. Available from: $<$ https://www.cnabrasil. org.br/noticias/cenario-para-2019-e-de-safra-maior-de-graos-altado-pib-e-do-faturamento-do-agro>. Accessed: Jan. 10, 2019.

DAN, H. A. et al. Mixture of Brachiaria ruziziensis seeds with urea aiming to implement an integrated crop-livestock system. Revista Caatinga, v.24, n.4, p.68-73, 2011. Available from: <https:// periodicos.ufersa.edu.br/index.php/caatinga/article/view/2088/ pdf $>$. Accessed: Mar. 16, 2017.

DEBEZ, A. et al. Salinity effects on germination, growth, and seed production of the halophyte Cakile maritima. Plant Soil, v.262, n.1-2, p.179-189, 2004. Available from: <https://link.springer.com/ article/10.1023/B:PLSO.0000037034.47247.67>. Accessed: Jan. 29, 2018. doi: 10.1023/B:PLSO.0000037034.47247.67.

DELATORRE-HERRERA, J. and PINTO, M. Importance of ionic and osmotic components of salt stress on the germination of four quinua (Chenopodium quinoa willd.) selections. Chilean Journal Agricultural Research, v.69, n.4, p.477-485, 2009. Available from: <http://www.bioline.org.br/pdf?cj09057>. Accessed: Jan. 08, 2019. doi: 10.4067/S0718-58392009000400001

DIAS-FILHO, M. B. Formação e Manejo de Pastagens. Belém, PA: Embrapa Amazônia Oriental, 2012. 9 p. (Embrapa Amazônia Oriental. Comunicado técnico, 235). Available from: <http:// ainfo.cnptia.embrapa.br/digital/bitstream/item/68489/1/OrientalComTec235.pdf>. Accessed: May, 15, 2017.

FERRARI, A. C. et al. Desenvolvimento inicial de milho em função e doses de ureia aplicadas em semeadura. In: CONGRESSO BRASILEIRO DE CIÊNCIA DO SOLO, 34., 2013, Florianópolis, SC. Anais.Vicosa MG: Sociedade Brasileira de Ciência do Solo, 2013.

FERREIRA, D. F. SISVAR: a Guide for its Bootstrap procedures in multiple comparisons. Ciência Agrotecnologia, v.38, n.2, p.109-112, 2014. Accessed: Sep. 25, 2017. doi: 10.1590/S141370542014000200001 .

FOLONI, J. S. S. et al. Installation of forage species as a function of soil depth and contact with npk fertilizer formulation. Pesquisa Agropecuária Tropical, v.39, n.1, p.7-12, 2009. Available from: $<$ https://www.revistas.ufg.br/pat/article/view/3313>. Accessed: Jun. 22, 2017. 
LIMA, E. V. et al. Mixture of Brachiaria brizantha seeds with NPK fertilizer. Ciência Rural, v.40, n.2, p.441-444, 2010 Available from: <http://www.scielo.br/scielo.php?script=sci_artt ext\&pid=S0103-84782010000200035>. Accessed: Jun. 10, 2016. doi: $10.1590 / \mathrm{S} 0103-84782010005000003$.

LIMA, E. V. et al. Triple superphosphate as a means to distribute Brachiaria brizantha seeds for pasture renovation in the Amazon Region. Revista Brasileira de Zootecnia, v.38, n.8, p.796-800, 2009. Accessed: Jun. 10, 2016. doi: 10.1590/S151635982009000500003 .

MAGUIRE, J. D. Speed of germination-aid selection and evaluation for seedling emergence and vigor 1. Crop Science, v.2, p.176-177, 1962. Available from: <https://dl.sciencesocieties.org/ publications/cs/abstracts/2/2/CS0020020176>. Accessed: Jul. 10, 2017. doi: 10.2135/cropsci1962.0011183X000200020033x

MARCOS-FILHO, J. Fisiologia de sementes de plantas cultivadas. 2. ed., Londrina: ABRATES, p. 660, 2015. 660 p.

MASETTO, T.E. et al. Germination of Urochloa ruziziensis seeds according to substrate water availability and seeds moisture content. Pesquisa Agropecuária Tropical, v.43, n.4, p.385-391, 2013. Accessed: Aug. 12, 2016. doi: 10.1590/S198340632013000400010 .

MATEUS, G. P. et al. Sources and time of contact of mineral fertilizer with Brachiaria brizantha seeds as related with germination. Revista Brasileira de Ciências do Solo, v.31, n.1, p.177-183, 2007. Accessed: Jun. 10, 2016. doi: 10.1590/S010006832007000100018 .

MATTEI, E. et al. Seed germination and development of Brachiaria ruziziensis after different periods of contact with fertilizers. Journal of Agronomic Sciences, v.4, n.2, p.20-30, 2015. Available from: <http://www.dca.uem.br/V4N2/03-Eloisa. pdf $>$. Accessed: Jun. 16, 2018.

PARIZ, C. M. et al. Physiological quality of Brachiaria seeds and dry mass yield estimate under different irrigated crop-livestock integration systems. Pesquisa Agropecuária Tropical, v.40, n.3, p.330-340, 2010. Available from: < https://www.revistas.ufg.br/
pat/article/viewFile/6590/7809>. Accessed: May, 18, 2018. doi: 10.5216/pat.v40i3.6590

PEREIRA, M. R. R. et al. Influence of saline and water stress on germination of Urochloa decumbens and Urochloa ruziziensis. Bioscience Journal, v.28, n.4, p.537-545, 2012. Available from: $<$ http://www.seer.ufu.br/index.php/biosciencejournal/article/ view/13447>. Accessed: May, 25, 2018.

PERES, A. R. et al. Physiological potential of Brachiaria brizantha cv. Marandu seeds kept in contact with phosphatic fertilizers. Revista Brasileira de Sementes, v.34, n.3, p.424432, 2012. Accessed: Nov. 22, 2016. doi:10.1590/S010131222012000300009 .

SANGOI, L. et al. Maize initial development as affected by nitrogen sources and rates at sowing time. Revista Biotemas, v.22, n.4, p.53-58, 2009. Avaliable from: $<$ https://periodicos.ufsc. br/index.php/biotemas/article/view/2175-7925.2009v22n4p53>. Accessed: Jan. 15, 2019. doi: 10.5007/2175-7925.2009v22n4p53>

SILVA, V. N. et al. Electrical conductivity test with parts of bean seeds. Revista de Ciências Agrárias, v.37, n.2, p.206-213, 2014 Avaliable from: $<$ http://www.scielo.mec.pt/scielo.php?script=sci arttext\&pid=S0871-018X2014000200011>. Accessed: Jun. 1, 2013.

SOARES, M. M. et al. Water and salt stress in soybean seeds classified in different sizes. Pesquisa Agropecuária Tropical, v.45, n.4, p.370-378, 2015. Accessed: May, 27, 2018. doi: 10.1590/1983-40632015v4535357.

TORRES, S.B. et al. Assessment of rocket seed vigor through respiration activity. Horticultura Brasileira, v.34, n.4, p.561-564, 2016. Accessed: Jun. 18, 2018. doi:10.1590/S0102-053620160416.

UNITED STATES DEPARTMENT OF AGRICULTURE USDA. Livestock and Poultry. Available from: <https://apps.fas. usda.gov/psdonline/app/index.html\#/app/downloads>. Accessed: Jan. 05, 2019

VIEIRA, R.D.; KRZYZANOWSKI, F.C. Teste de condutividade elétrica. In: KRZYZANOWSKI, F.C.; VIEIRA, R.D.; FRANÇA NETO, J.B. (Ed.). Vigor de sementes: conceitos e testes. Londrina: ABRATES, p. 1-26, 1999. 